\title{
DETERMINING WATER QUALITY INDEX USING THE PHYSICO-CHEMICAL ATTRIBUTES FOR GROUNDWATER AND SPRING IN VICINITY OF KAWASING RESERVE FOREST, ASSAM, NORTH-EAST INDIA
}

\section{Sangeeta Deka, ${ }^{1 *}$ Lal Bihari Singha ${ }^{2}$ and Om Prakash Tripathi ${ }^{3}$}

${ }^{1}$ Department of Forestry, North Eastern Regional Institute of Science and Technology (Deemed to be University) Nirjuli, Arunachal Pradesh, India

${ }^{2}$ Department of Life Sciences (Botany), Manipur University, Canchipur, Imphal, India ${ }^{3}$ Dept. of Environmental Sciences, Mizoram University, Tanhril, Aizawl, Mizoram, India

*Corresponding author Email: deka_sangeeta@yahoo.co.in

\begin{abstract}
The current study attempts to assess the physical and chemical attributes and water quality index (WQI) of spring and groundwater in vicinity of Kawasing Reserve forest (KRF) in Kamrup district of Assam, to understand its suitability for various uses including drinking purpose. The detailed investigation was carried out in two types of water sources (spring and ground water in form of well). The water samples were collected along a distance gradient from the mid-range of the forest patch to find out the influence of forest on water characteristics. It is argued that natural spring water (SWS) could be the key basis of drinking water for populations around the forest vicinity. It was observed that the SWS possessed $\mathrm{pH}$, dissolved oxygen and total alkalinity beyond the permissible limits of Indian standards/ICMR standards and other parameters showed values well within the prescribed limit of standard. On other hand, the ground water system (GWS) possessed dissolved oxygen, total hardness and magnesium $\left(\mathrm{Mg}^{2+)}\right.$ beyond permissible limit and rest parameters were within the prescribed limit of standards. The findings reveal that the quality of SWS was better than that of GWS. The WQI indicates that spring water system falls under the "excellent" category (WQI: 25.06 6.03) while ground water system denotes "poor" category (154.98+19.03). Moreover, SWS and GWS found 100 percent and 22.5 percent suitable for human consumption. The increase in WQI value with increase in distance suggesting a negative correlation in terms of water quality or water quality degrades with increase in distance from the mid-range of KRF. The outcome of present study may be a guiding bacon to the inhabitants in vicinity of KRF with respect to water resource utilization. Systematic and sustainable water quality management approaches especially for GWS, to be adopted for clean water in surroundings of Kawasing Reserve forest.
\end{abstract}

Key words: Ecosystem Services; Physico-Chemical; Sustainable; Water Quality Index

\section{Introduction}

The term "water quality" literally denotes the physical, chemical, and biological characteristics of water for its suitability for a particular use (Pike et al., 2010). Various anthropogenic activities are responsible for change in the physical, chemical and biological structure of the water, leading to deteriorated water resource. The major factors causing alteration of water quality includes change in vegetation cover, construction of various conveniences on the rivers, use of fertilizers and pesticide in agricultural fields, which directly affect the micro climate of the water making the water quality unhealthy for aquatic life as well as human uses. Forests have a multidirectional interaction with the freshwater systems, and are responsible for regulating the quality of water in various ways- through soil stability and sediment load, fishing and hatching activities, presence of various tree 
species and its impact on acidification of water, management of downstream water logging and salinity; influencing the availability of water for irrigation systems and many more (Dudley and Stolton, 2003). Groundwater systems (GWSs) are the water bodies that rely on groundwater to maintain their health and vigour. The GWSs are considered vital features in the site that necessitate access to ground water to preserve its current composition, structure and function (Eamus, 2009). Like other systems, GWS also provides ecosystem services which are valuable at various levels. Provisioning services like drinking water, water for industrial use, irrigation etc. are among the tangible goods while regulating services such as water retention and drainage, surface water supply, water purifying and filtering effect of soil and water supporting services as function of biogeochemical cycles and cultural services such as aesthetical and ethical values of GWS are among the intangible goods essential for sustenance of a healthy environment (Tuinstra and Wensem, 2014). Springs are water resources formed in any sort of rock when excavations on hills and valley bottoms intersect a flowing body of ground water at or below the water table, below which the sub-surface layer is saturated ( www.usgs.gov). Springs are the main source of water for the people in many parts of the country and worldwide (Taloor and Singh, 2020; Amen, 2019, Barakat et al., 2018; Mofor et al., 2017; Sammoudi et al., 2019; Ganiyu et al., 2017).

The people depend on springs as a source of potable water and other domestic and agricultural purposes and mostly used without any pre-treatment. Springs are therefore considered inexpensive and best-quality source of water (Ameen, 2019). The optimum accessibility and good quality of water in several regions of the world are under serious threat due to unsustainable use of groundwater, contamination of surface water and the impact of climate change (IPCC, 2007; Ameen, 2019). This study emphasis the assessment of ground (well) and spring water quality for human consumption, based on physical and chemical parameters and water quality index (WQI) enumeration of these water samples. The WQI is an important model to detect the status of water quality and has been functional for both ground and surface water system throughout the world since the last few decades (Ramakrishnaiah et al., 2009; Kawo and Karuppannan, 2018; Samantray et al., 2009; Bora and Goswami, 2017; Shah and Joshi, 2017; Singh and Kamal, 2014; Seth et al., 2016; Dash et al., 2015; Bhutiani et al., 2014; Krishnan et al., 2016; Kaviarasan et al., 2016; Vishnu Radhan et al., 2015; Yadav et al., 2015). The WQI model enables to convert a complex set of water quality data into simple information, making it easy to understand the status water source (Balan et al., 2012). WQI provides state of water with a single value utilizing multi parameters of water quality (Abbasi, 2002). Since the inhabitants in vicinity of Kawasing forest primarily depends on wells (GWS) and spring (SWS) water, the study aimed to qualify the water from both the sources. The objective of this research is also to find the effect of the presence of forest stand on water quality of the study area.

\section{Study Area}

This study is conducted in vicinity of the Kawasing Reserve forest in Kamrup district of Assam (Fig. 1). The temperature ranges between $10^{\circ} \mathrm{C}$ and $34^{\circ} \mathrm{C}$ and relative humidity accounts for $67-90$ percent with annual precipitation of $120 \mathrm{~cm}$ to $230 \mathrm{~cm}$. The forested catchment is characterized by hilly terrain with natural forest cover and steep slope down the hill connecting the even land. The even land could be categorised as agricultural lands, water bodies, human habitations and several stream networks connecting the perennial springs flowing down the forest. The reserve forest falls under older alluvium hydrogeological formation (CGWB-Kamrup, 2013). Older alluvium has a suitable prospect for shallow tube wells, deep tube well up to $100 \mathrm{~m}$ depth and dug wells feasible at foot hills. 
Figure 01: (a) Location of The Study Area (b) Image of Sampling Locations

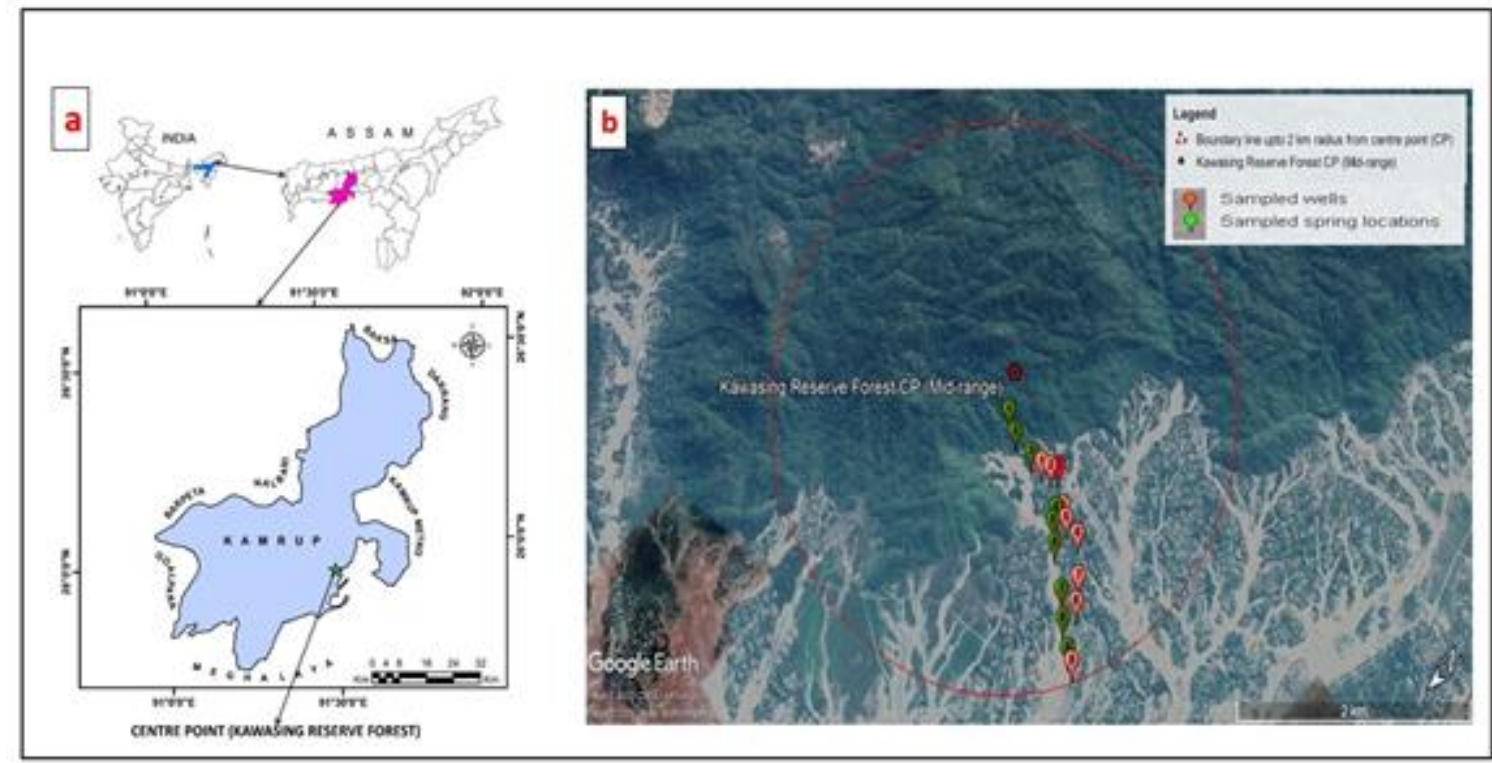

\section{Sampling Technique and Analysis}

Within the study area, the water systems of two types were selected on the basis of distance gradient from the forest. First category included artificial hand-dug wells and the second category natural spring flowing down the hill slope through the KFR. Both the categories of water bodies are largely used for drinking purpose. Water samples were collected at different locations along a distance gradient up to a distance of $2 \mathrm{~km}$ away from the mid-range of the forest patch. GPS points were collected using handheld GPS device (Garmin) at different locations along a flowing natural spring and also at various wells set within human habitation areas along a distance gradient from the forest stand to study the physico-chemical properties of water and to enumerate the WQI of the two different categories of water sources of the study area. A total of 9 wells and 9 springs from different locations within were surveyed and collected the samples. The wells were kutcha (entirely hand-dug) or concrete ring- walled. A few wells were later seen unused due to structural instability. The water samples from selected sites were collected and analysed for various physical and chemical properties like, temperature, $\mathrm{pH}$, electrical conductivity, total dissolved solids, total hardness, chloride, total alkalinity, Calcium $\left(\mathrm{Ca}^{2+}\right)$ and Magnesium $\left(\mathrm{Mg}^{2+}\right)$. The standard methods for the examination of water and wastewater as prescribed by APHA (2005) was followed for examination of water quality attributes. Temperature was measured using thermometer and expressed as degree centigrade $\left({ }^{\circ} \mathrm{C}\right)$. Electrode method was used to determine the $\mathrm{pH}$ of water. The conductivity meter of the SWAK was used for the analysis of electrical conductivity (EC) of water and the results were expressed as micro Siemens. Total dissolved solids (TDS) was estimated with the meter inbuilt in the SWAK, and the results expressed in ppm (parts per million) or $\mathrm{mgL}^{-1}$. The water analysis kit was used to measure the dissolved oxygen content and values were expressed in $\mathrm{mgL}^{-1}$ Total hardness was estimated using EDTA titration method, and values were expressed in $\mathrm{mgL}^{-1}$. Mohr's Argentometric method was used to determine chloride content in water, and values were expressed in $\mathrm{mgL}^{-1}$. The $\mathrm{Ca}^{2+}$ and $\mathrm{Mg}^{2+}$ were analysed using titrimetric method, and values were expressed in $\mathrm{mgL}^{-1}$.

\section{Water Quality Index (WQI) Analysis}

Weighted arithmetic index method formulated by Brown et al. (1970) was followed to calculate the WQI where all the values of chemical parameters were taken into consideration with a single expression. The equation used in this method is as follows: 


$$
W Q I=\sum_{i}^{n} r_{i} w_{i} / \sum_{i}^{n} w_{i}
$$

Where $\mathrm{n}=$ water quality parameters or variables used

$r_{i}=$ quality rating of $i^{\text {th }}$ water quality variable

$w_{i}=$ relative unit weight of $i^{\text {th }}$ water quality variable

The value of $r_{i}$ is computed using the following equation:

$$
\left.r_{i}=100\left\{\left(V_{i o}-V_{i p}\right)\right\} /\left(V_{p}-V_{i p}\right)\right\}
$$

Where $V_{i o}=$ Observed value of $i^{\text {th }}$ water quality parameter

$V_{i p}=$ Ideal value of $i^{\text {th }}$ water quality parameter in pure water

$V_{p}=$ Standard permissible value of the $i^{\text {th }}$ water quality parameter

All the ideal values $\left(V_{i p}\right)$ are taken as zero for drinking water except $\mathrm{pH}$ and DO (Tripaty and Sahu, 2005; Boah et al., 2014). The ideal value for $\mathrm{pH}$ is 7.0 (for natural/pure water) and a permissible value is 8.5 (for polluted water) and for dissolved oxygen (DO) is $14.6 \mathrm{~g} / \mathrm{l}$.

The unit weight $\left(w_{i}\right)$ of the different water parameters are inversely proportional to the recommended standards for the corresponding parameters. The value is calculated as follows:

$$
w_{i}=k / V_{p}
$$

Where, the constant of proportionality $(\mathrm{k})$ is calculated using the equation:

$$
k=1 / \sum_{i}^{n}\left(\frac{1}{V_{p}}\right)_{i} \quad(i=1,2,3 \ldots \ldots . n)
$$

Table 01: Water Quality Status Based on WQI Values and their Probable Usage (Ramakrishnaiah et al., 2009; Sahu and Sikdar, 2008; Kawo and Karuppannan, 2018)

\begin{tabular}{|l|l|l|}
\hline $\begin{array}{l}\text { WQI value } \\
\text { range }\end{array}$ & Water quality inference & Probable usage \\
\hline Less than 50 & Excellent & Drinking, irrigation and industrial \\
\hline $51-100$ & Good & Drinking, irrigation and industrial \\
\hline $101-200$ & Poor & Irrigation and industrial \\
\hline $201-300$ & Very poor & Irrigation \\
\hline More than 300 & Unfit for drinking and aquaculture & Pre-treatment required \\
\hline
\end{tabular}

\section{Results and Discussion}

The pre-requisite condition in calculating WQI is the estimation of relative unit weight $\left(\mathrm{w}_{\mathrm{i}}\right)$ of each parameter taken into account for water quality assessment. To achieve the unit weights, it is necessary to convert the units of various parameters into a common scale. In this study, all the parameters were presented in milligram per litre $\left(\mathrm{mgL}^{-1}\right)$, excluding $\mathrm{pH}$ (dimensionless) and electrical conductivity (micro Siemens/centimetre). The Bureau of Indian Standard (BIS, 2003) and the Indian Council of Medical Research (ICMR, 1975) standards for drinking water with the relative weights assigned to the respective parameters were used for calculating the WQI are tabulated in Table 2. Values highlights that dissolved oxygen (0.50019) contributed the maximum weightage on the WQI followed by $\mathrm{pH}$ (0.38476), and total dissolved solids (TDS) contributed the minimum weightage on the index value. 
Table 02: Relative Weight of Chemical Parameters and Drinking Water Standards Recommended by Indian Standard Institute and ICMR

\begin{tabular}{|l|c|c|}
\hline Parameters & Indian*/ICMR standards $^{*}$ & Relative weight $_{\left(\mathbf{w}_{\mathbf{i}} \mathbf{)}\right.}$ \\
\hline $\mathrm{pH}$ & 6.5 & 0.38476 \\
\hline Electrical conductivity & $300^{*}$ & 0.00834 \\
\hline Total dissolved solids & $500^{*}$ & 0.00500 \\
\hline Dissolved oxygen & $5^{\#}$ & 0.50019 \\
\hline Water hardness & $300^{*}$ & 0.00834 \\
\hline Chloride & $250^{*}$ & 0.01000 \\
\hline Alkalinity & $120^{\#}$ & 0.02084 \\
\hline Magnesium & $30^{*}$ & 0.05002 \\
\hline Calcium & $75^{*}$ & 0.01250 \\
\hline & & $\sum W_{n}=1.0$ \\
\hline
\end{tabular}

*Expressed in milligrams per litre excluding $\mathrm{pH}$ and $\mathrm{EC}$.

The respective mean values of all variables from both the water system and the respective contributing scores to the WQI value are presented in the Table 3 . The study revealed that the water characteristics of SWS was superior than that of ground water system as water quality index value of the former system was found to be quite lower than the later (Table 3). In the ground water system, parameters like $\mathrm{pH}(100.89)$ and dissolved oxygen (41.99) were found to be the most influencing factor for a higher value of WQI. But in case of spring water system dissolved oxygen (39.18) is the only factor found influencing the WQI score on a higher side. The $\mathrm{pH}$ value was seen to have a positive influence on the water quality of the spring water system as the contributing score of $\mathrm{pH}$ to WQI value was negligible which compensated and brought back the final WQI value to a very lower range under the "excellent" category of water quality status (Table 1). As per the categorization of water quality status based on WQI value, the ground water system (154.98 \pm 19.03$)$ falls under the "poor" category while spring water system $(25.06 \pm 6.03)$ under the "excellent" category.

Table 03: Comparative Account of WQI Values of Ground Water System and Spring Water System along with the Corresponding Observed Values of the Parameters Used

\begin{tabular}{|c|c|c|c|c|c|c|}
\hline \multirow{2}{*}{$\begin{array}{c}\text { Water } \\
\text { Quality } \\
\text { Parameters }\end{array}$} & \multicolumn{3}{|c|}{ Ground water system } & \multicolumn{3}{|c|}{ Spring water system } \\
\hline & $\begin{array}{l}\text { Observed } \\
\text { values }\end{array}$ & $\begin{array}{c}\text { Quality } \\
\text { rating } \\
\left(r_{i}\right)\end{array}$ & $r_{i} W_{i}$ & $\begin{array}{l}\text { Observed } \\
\text { values }\end{array}$ & $\begin{array}{c}\text { Quality } \\
\text { rating } \\
\left(r_{i}\right)\end{array}$ & $r_{i} W_{i}$ \\
\hline $\mathrm{pH}$ & 5.69 & 262.22 & 100.8934 & 7.28 & -68.00 & -20.0077 \\
\hline $\begin{array}{l}\text { Electrical } \\
\text { conductivity }\end{array}$ & 70.00 & 23.33 & 0.194519 & 40.00 & 13.33 & 0.111154 \\
\hline $\begin{array}{l}\text { Total } \\
\text { dissolved } \\
\text { solids }\end{array}$ & 120.00 & 24.00 & 0.120046 & 48.00 & 9.60 & 0.048018 \\
\hline $\begin{array}{l}\text { Dissolved } \\
\text { oxygen }\end{array}$ & 6.54 & 83.95 & 41.9895 & 7.08 & 76.04 & 39.18171 \\
\hline $\begin{array}{l}\text { Water } \\
\text { hardness }\end{array}$ & 341.87 & 113.96 & 0.949994 & 17.92 & 5.97 & 0.049797 \\
\hline Chloride & 19.89 & 7.95 & 0.079584 & 24.00 & 9.60 & 0.096037 \\
\hline Alkalinity & 118.44 & 98.70 & 2.057117 & 135.44 & 112.85 & 2.351944 \\
\hline Magnesium & 50.48 & 168.28 & 8.4173 & 15.44 & 51.47 & 2.574321 \\
\hline \multirow[t]{3}{*}{ Calcium } & 16.97 & 22.63 & 0.2829 & 18.04 & 24.05 & 0.300782 \\
\hline & \multicolumn{2}{|c|}{$\sum W_{n}=1.00000$} & $\sum r_{i} w_{i}=154.9845$ & \multicolumn{2}{|c|}{$\sum W_{n}=1.00000$} & $\sum r_{i} w_{i}=25.06088$ \\
\hline & \multicolumn{3}{|c|}{$W Q I=\sum_{i}^{n} r_{i} w_{i} / \sum_{i}^{n} w_{i}=154.9845$} & \multicolumn{3}{|c|}{$W Q I=\sum_{i}^{n} r_{i} w_{i} / \sum_{i}^{n} w_{i}=25.06088$} \\
\hline
\end{tabular}

The ground water quality assessment included sampling of 9 wells along a distance gradient in three classes $\left(W_{500-1000} / W_{1000-1500} / W_{1500-2000}\right)$ i.e., 500 to 1000 meter, 1000 to 1500 meter and 1500 to 2000 meter away from the mid-range of the Kawasing Reserve forest. These wells were selected randomly, three (3) each under each class of distance 
range. Under the GWS, 6 out of 9 wells belong to "poor" category while 2 were under "good" category and only one was reported "very poor" and its respective WQI values are presented in Table 4. Similarly, a total of 9 locations along the spring flow in three classes of distance gradient $\left(S_{500-1000} / S_{1000-1500} / S_{1500-2000}\right)$ were sampled for water quality assessment, each class having three sampling locations. In the SWS, 7 out of 9 possessed "excellent" status of water quality based on WQI values with an exception to location (S7 and S9) which fall under the "good" category with a considerable higher value of WQI (>50) as shown in Table 4.

Classifying the water system (GWS and SWS) on distance gradient and considering the mean water quality index (MWQI) value of the sampled well and spring locations respectively under corresponding class of distance range we obtained a significant result that water quality index value increases with increase in distance from the mid-range of Kawasing forest. Under the ground water system, the MWQI values increases with increase in distance (Table 4 and Fig. 2). A similar trend in results was observed for the spring water system (Table 4 and Fig. 3).

Table 04: Water Quality Index (WQI) of Individual Sampling Locations and Quality Inferences and Along the Distance Gradient

\begin{tabular}{|c|c|c|c|c|c|}
\hline $\begin{array}{c}\text { Sample } \\
\text { ID }\end{array}$ & WQI value & $\begin{array}{l}\text { Water quality } \\
\text { inference }\end{array}$ & $\begin{array}{c}\text { Sample } \\
\text { ID }\end{array}$ & WQI value & $\begin{array}{l}\text { Water quality } \\
\text { inference }\end{array}$ \\
\hline W1 & 78.0260 & Good & $\mathrm{S} 1$ & 11.11723 & Excellent \\
\hline W2 & 121.6215 & Poor & S2 & 6.656989 & Excellent \\
\hline W3 & 98.78181 & Good & S3 & 7.891602 & Excellent \\
\hline W4 & 196.1628 & Poor & S4 & 23.95247 & Excellent \\
\hline W5 & 186.3825 & Poor & S5 & 12.65996 & Excellent \\
\hline W6 & 147.2068 & Poor & S6 & 17.79988 & Excellent \\
\hline W7 & 195.2440 & Poor & S7 & 56.21569 & Good \\
\hline W8 & 146.2612 & Poor & S8 & 35.38022 & Excellent \\
\hline W9 & 225.1735 & Very poor & S9 & 53.87388 & Good \\
\hline \multicolumn{6}{|c|}{ WQI values and inferences along the distance gradient } \\
\hline Distance & $\begin{array}{l}\text { MWQI } \\
\text { value }\end{array}$ & $\begin{array}{c}\text { Water quality } \\
\text { inference }\end{array}$ & Distance & $\begin{array}{l}\text { MWQI } \\
\text { value }\end{array}$ & $\begin{array}{c}\text { Water quality } \\
\text { inference }\end{array}$ \\
\hline$W_{500-1000}$ & 99.48 & Good & $\mathrm{S}_{500-1000}$ & 8.56 & Excellent \\
\hline$W_{1000-1500}$ & 176.58 & Poor & $S_{1000-1500}$ & 18.14 & Excellent \\
\hline$W_{1500-2000}$ & 188.89 & Poor & $\mathrm{S}_{1500-2000}$ & 48.49 & Excellent \\
\hline
\end{tabular}

Figure 02: Graphical represantation of individual water quality index (IWQI) of the sampled wells and the mean water quality index (MWQI) along distance (in meter) gradient of ground water system

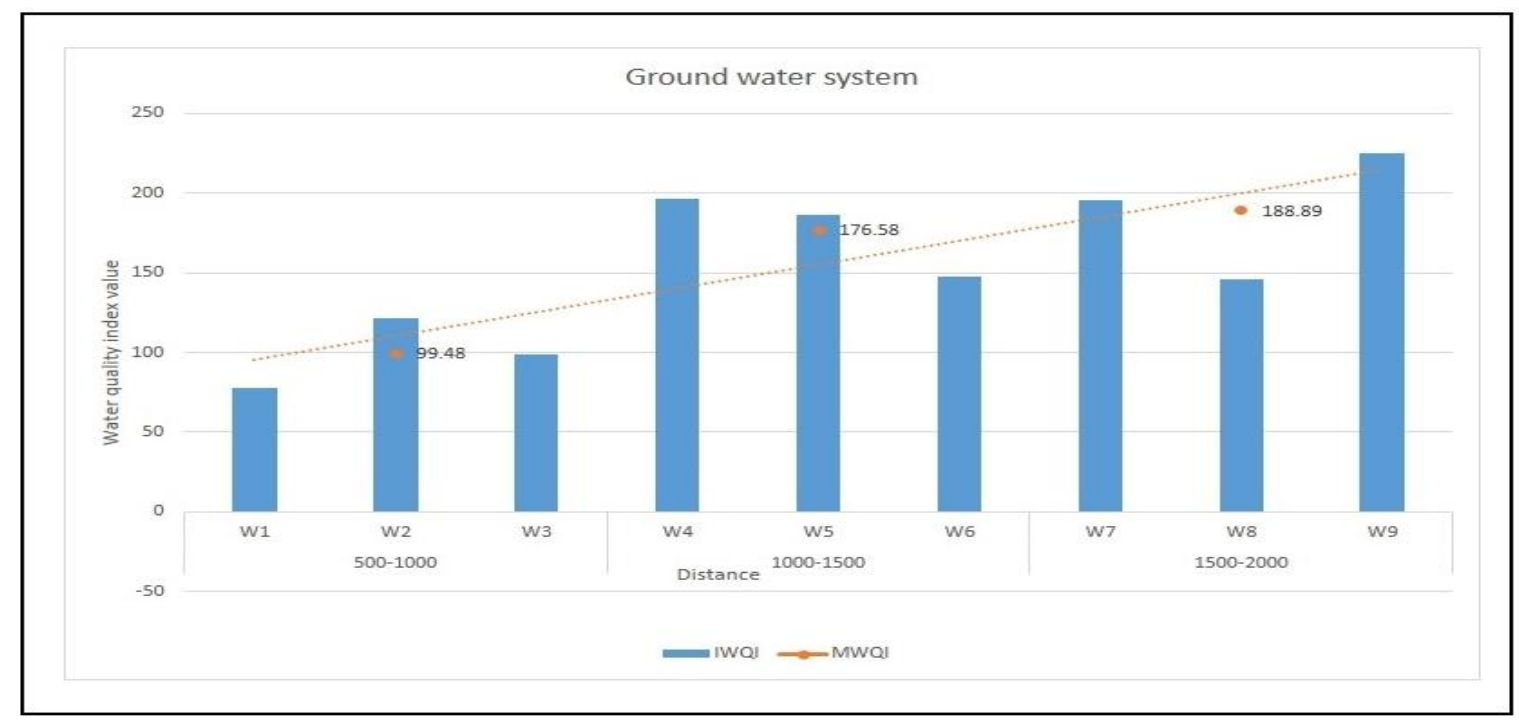


Figure 03: Graphical represantation of individual water quality index (IWQI) of the sampled spring locations and the mean water quality index (MWQI) along distance (in meter) gradient of spring water system

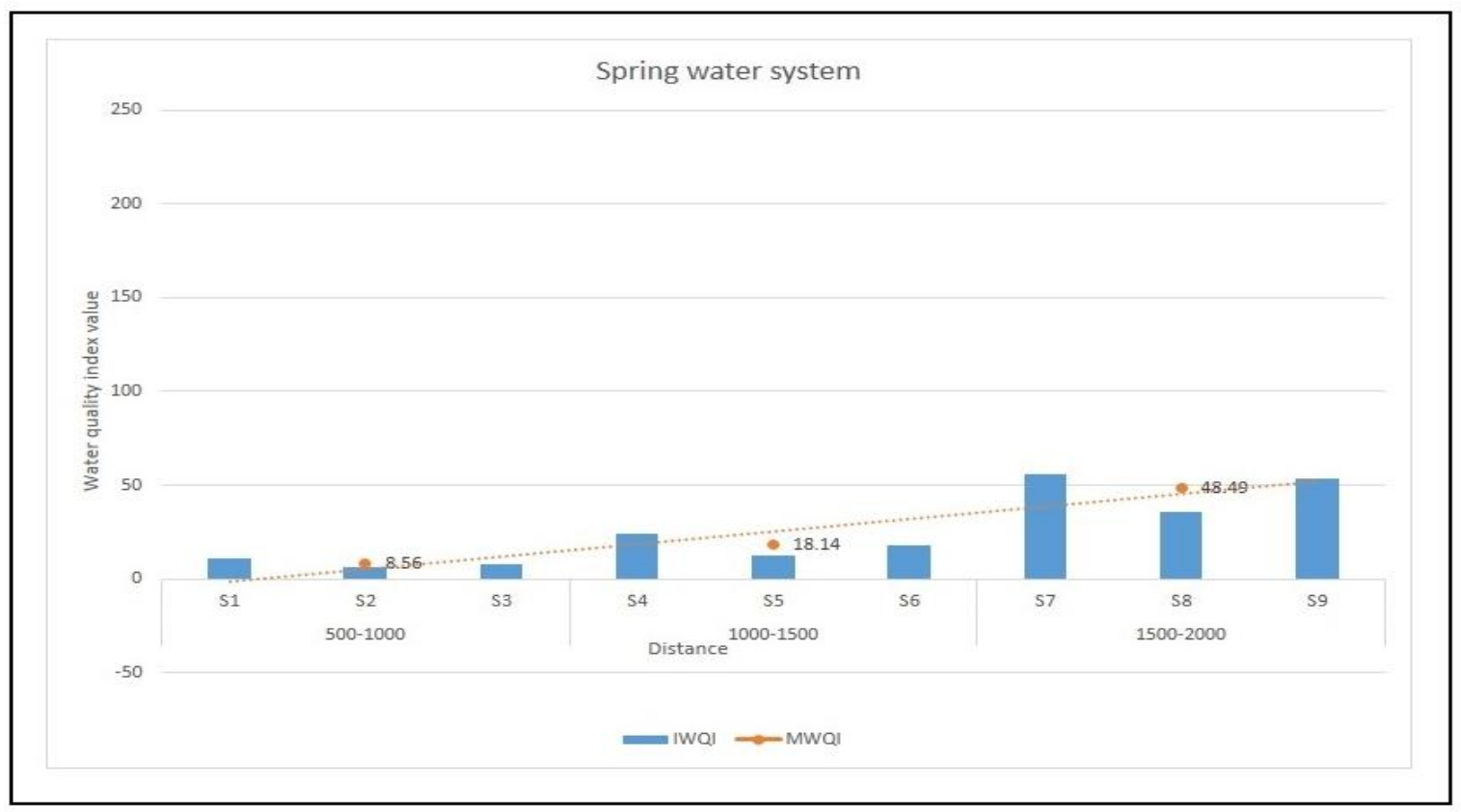

The findings on the quality of water are in conformity with the works of several authors (Lalchhingpuii et al., 2011; Lalparmawii and Mishra, 2016; Thasangzuala et al., 2014; Mishra and Chenkual, 2014; Chenkual and Mishra, 2016; Sunar and Mishra, 2016; Laldinpuii and Mishra, 2019; Lalhmangaihzuali et al., 2019). Mishra and Lalhruaizeli (2009) also reported a similar result in a study on spring water quality status in Aizawl, Mizoram, India.

The findings on WQI is supported by the work of Sunar and Mishra (2018) who studied WQI of Serlui river of Mizoram. Based on distance gradient, the WQI values increased with increase in distance which suggests a positive correlation between WQI value and the dimension of distance, while it suggested a negative correlation with respect to water quality. In other words, results reveal that water quality degrades with increase in distance from the mid-range of Kawasing forest, supporting the statement that tropical forest cover act as a good indicator of water quality (Mello et.al 2018). In the present days, tropical forests have been facing tremendous threat due to land use change, deforestation and fragmentation like activities and causing degradation of water quality. Over extraction of timber, mis-utility and severe pollution were recognised as the major drivers for degradation of the water resource (Calder, 2007). Therefore, it is important to study the role of forest cover as an indicator of water quality in different landscapes.

\section{Conclusions}

The present study is an effort to assess quality of drinking water sources prevalent in the vicinity of Kawasing reserve forest, and to make aware the people settled in vicinity who are using such water for various purposes. The assessment of water quality was carried out from 18 different locations of two different water system viz., ground water system ( 9 locations) and spring water system (9 locations). The only physical parameter analysed in the study was temperature which was not included in the WQI score computation. It was found that 11.11 percent, 22.22 percent and 66.67 percent of water samples were considered as 'very poor', 'good' and 'poor' water quality, respectively under the ground water system. On the other hand, 22.22 percent and 77.78 percent of water samples were considered as 'good' and 'excellent' water quality under the spring water system. Of water samples analysed, only 22.22 percent of GWS and 100 percent of SWS may be considered 
suitable for human use. Based on findings, it can be argued that natural spring water could be the primary source of drinking water for the inhabitants in vicinity of forest instead of the wells (ground water source). 'Poor' or 'very poor' water quality of the GWS might be due to structural instability of wells from where water samples were collected. Based on on-sight observation, the sampled wells were found mostly hand-dug kutcha (without concrete walls). Sanitation and domestic sewage outflows found unmanaged and improper. Moreover, it also facilitates easy runoff from surroundings and contamination of ground water through percolating water, making water unhealthy and unfit for human consumption. On the contrary, the spring water system is still pristine. There exists very little human interference to the SWS. Analysis of individual water quality parameter depicts that GWS possessed all the parameters were within the permissible limits of the chosen standards except for dissolved oxygen, total hardness and magnesium $\left(\mathrm{Mg}^{2+)}\right.$ which were closer to or exceeded the permissible limit of Indian Standard Institute/ICMR standards. Similarly, SWS possessed $\mathrm{pH}$, dissolved oxygen and total alkalinity beyond permissible limits. The findings of present study are not only important as research data but also has a tremendous significance as ground reality. The outcome of present study may act as guiding bacon to the inhabitants settled in vicinity of the Kawasing forest. For maintaining a healthy ecosystem and a hazard free health, systematic and sustainable water quality management of GWS and necessary pre-treatment of water are pre-requisite.

\section{Acknowledgements}

Authors thankfully acknowledge the University Grants Commission, New Delhi for financial assistance through National Fellowship for Higher Education. The authors are also very much thankful to the Department of Forestry, NERIST for providing all necessary facilities for the research work.

\section{References}

1. Abbasi, S. A. (2002). Water quality indices state-of-the-art. Pondicherry: Pondicherry University, Centre for Pollution Control \& Energy Technology.

2. Ameen, H. A. (2019). Spring water quality assessment using water quality index in villages of Barwari Bala, Duhok, Kurdistan Region, Iraq. Applied Water Science, 9(8), pp. 176.

3. American Public Health Association. (2005). Standard methods for the examination of water and wastewater. APHA Washington DC, USA.

4. Assessed through http://www.usgs.gov.

5. Balan, I. N., Shivakumar, M. and Kumar, P. M. (2012). An assessment of groundwater quality using water quality index in Chennai, Tamil Nadu, India. Chronicles of Young Scientists, 3(2), pp.146.

6. Barakat, A., Meddah, R., Afdali, M. and Touhami, F. (2018). Physicochemical and microbial assessment of spring water quality for drinking supply in Piedmont of Béni-Mellal Atlas (Morocco). Physics and Chemistry of the Earth, Parts A/B/C, 104, pp.39-46.

7. Bhutiani, R., Khanna, D. R., Kulkarni, D. B. and Ruhela, M. (2016). Assessment of Ganga river ecosystem at Haridwar, Uttarakhand, India with reference to water quality indices. Applied Water Science, 6(2), pp.107-113.

8. BIS, 2003. Indian standard drinking water specifications IS10500:1991, Edition 2.2 (2003-2009). Bureau of Indian Standards, New Delhi.

9. Boah, D. K., Twum, S. B. and Pelig-Ba, K. B. (2015). Mathematical computation of water quality index of Vea dam in upper East region of Ghana. Environmental Sciences, 3(1), pp.11-16.

10. Bora, M. and Goswami, D. C. (2017). Water quality assessment in terms of water quality index (WQI): case study of the Kolong River, Assam, India. Applied Water Science, 7(6), pp. 31253135.

11. Brown, R. M., McClelland, N. I., Deininger, R. A. and Tozer, R. G. (1970). A WATER QUALITY INDEX- DO WE DARE. Water Sewage Works, 117(10), pp.339-343.

12. Calder, I. R. (2007). Forests and water-ensuring forest benefits outweigh water costs. Forest ecology and management, 251(1-2), pp.110-120.

13. Centaral Ground Water Board. (2013). Ground water information booklet of Kamrup \& Kamrup Metro District, Assam.

14. Chenkual, L. and Mishra, B.P. (2016). Assessment of seasonal variation in chemical characteristics of Tamdil lake, Mizoram, Northeast India. International Journal of Scientific Engineering and Applied Science, 2(7), pp. 157-164. 
15. Dash, A., Das, H. K., Mishra, B. and Bhuyan, N. K. (2015). Evaluation of water quality of local streams and Baitarani River in Joda area of Odisha, India. International Journal of Current Research, 7(3), pp.13559-13568.

16. de Mello, K., Valente, R. A., Randhir, T. O. and Vettorazzi, C. A. (2018). Impacts of tropical forest cover on water quality in agricultural watersheds in south-eastern Brazil. Ecological Indicators, 93, pp.1293-1301.

17. Dudley, N. and Stolton, S. (2003). Running pure: the importance of forest protected areas to drinking water. World Bank/WWF Alliance for Forest Conservation and Sustainable Use.

18. Eamus, D. (2009). Identifying groundwater dependent ecosystems: a guide for land and water managers. Land \& Water Australia.

19. Ganiyu, S. A., Olurin, O. T., Ojo, A. P., Badmus, B. S. and Jegede, O. A. (2017). Quality assessment of spring and well waters: an approach using water quality index and multivariate statistical analysis. The African Review of Physics, 12, pp.47-64.

20. I.C.M.R. (1975). Manuals of standards of quality for drinking water supplies. ICMR. New Delhi.

21. IPCC (2007). Climate change 2007: impacts, adaptation and vulnerability. Contribution of working group II to the fourth assessment report of the intergovernmental panel on climate change. Cambridge University Press, Cambridge, UK.

22. Kaviarasan, M., Geetha, P. and Soman, K. P. (2016). GIS-based ground water quality monitoring in Thiruvannamalai District, Tamil Nadu, India. In Proceedings of the international conference on soft computing systems (pp. 685-700). Springer, New Delhi.

23. Kawo, N. S. and Karuppannan, S. (2018). Groundwater quality assessment using water quality index and GIS technique in Modjo River Basin, central Ethiopia. Journal of African Earth Sciences, 147, pp.300-311.

24. Krishan, G., Singh, S., Singh, R. P., Ghosh, N. C. and Khanna, A. (2016). Water quality index of groundwater in Haridwar district, Uttarakhand, India. Water and Energy International, 58(10), pp. 55-58.

25. Lalchhingpuii, S. L., Lalramnghinglova, H. and Mishra, B. P. (2011). Assessment of the water quality of Tlawng river in Aizawl, Mizoram. Science Vision, 11, pp.72-76.

26. Laldinpuii, H. and Mishra. B.P. (2019). Assessment of the chemical characteristics of river SerluiA in Aizawl, Mizoram, North East India. Environment and Ecology, 37(4), pp.1141-1146.

27. Lalhmangaihzuali, S., Lalramnghinglova, H. and Mishra, B.P. (2019). Detail assessment of physico-chemical properties of perennial water within Aizawl City, Mizoram. Research review International Journal of Multidisciplinary, 4(10): pp.3-8.

28. Lalparmawii, S. and Mishra, B. P. (2012). Seasonal variation in water quality of Tuirial River in vicinity of the hydel project in Mizoram, India. Science Vision, 12(4), pp.159-163.

29. Mishra, B. P. Lalhruaizeli. (2009). Status of quality of spring water in western part of Aizawl city, Mizoram. Ecology, Environment \& Conservation, 15(1), pp. 159-165.

30. Mishra, B. P. and Chenkual, L. (2014). Physico-chemical characteristics of Tamdil in Mizoram, northeast India. Science Vision, 14, pp.200-206.

31. Mofor, N. A., Njoyim, E. B. T. and Mvondo-Zé, A. D. (2017). Quality Assessment of Some Springs in the Awing Community, Northwest Cameroon, and Their Health Implications. Journal of Chemistry.

32. Pike, R. G., Feller, M. C., Stednick, J. D., Rieberger, K. J. and Carver, M. (2010). Water quality and forest management. In Compendium of forest hydrology and geomorphology in British Columbia. RG Pike, TE Redding, RD Moore, RD Winker, \& KD Bladon (editors). BC Ministry of Forests and Range, Forest Science Program, Victoria, BC, and FORREX Forum for Research and Extension in Natural Resources, Kamloops, BC. Land Management Handbook, 66.

33. Ramakrishnaiah, C. R., Sadashivaiah, C. and Ranganna, G. (2009). Assessment of water quality index for the groundwater in Tumkur Taluk, Karnataka State, India. Journal of Chemistry, 6(2), 523-530.

34. Sahu, P. and Sikdar, P. K. (2008). Hydrochemical framework of the aquifer in and around East Kolkata Wetlands, West Bengal, India. Environmental Geology, 55(4), pp.823-835.

35. Samantray, P., Mishra, B. K., Panda, C. R. and Rout, S. P. (2009). Assessment of water quality index in Mahanadi and Atharabanki Rivers and Taldanda Canal in Paradip area, India. Journal of Human Ecology, 26(3), pp. 153-161.

36. Sammoudi, R., Chahlaoui, A., Kharoubi, A., Taha, I. and Taouraout, A. (2019). Development of a quality index model of spring waters: case study of the springs waters in Taanzoult plain (Aguelmam Sidi Ali RAMSAR site), Draa Tafilalt region, Morocco. In Proceedings of the 4th International Conference on Smart City Applications, pp. 1-9. 
37. Seth, R., Mohan, M., Singh, P., Singh, R., Dobhal, R., Singh, K. P. and Gupta, S. (2016). Water quality evaluation of Himalayan rivers of Kumaun region, Uttarakhand, India. Applied Water Science, 6(2), pp. 137-147.

38. Shah, K. A. and Joshi, G. S. (2017). Evaluation of water quality index for River Sabarmati, Gujarat, India. Applied Water Science, 7(3), pp. 1349-1358.

39. Singh, G. and Kamal, R. K. (2014). Application of water quality index for assessment of surface water quality status in Goa. Current World Environment, 9(3), pp. 994.

40. Sunar, S. and Mishra, B. P. (2016). Assessing the impact of Hydroelectric Power Project on the water quality of Serlui river in Kolasib district, Mizoram, North-East India. International Research Journal of Environmental Sciences, 5(9), pp. 40-44.

41. Sunar, S. and Mishra, B.P. (2018). Correlation and linear regression as a water quality monitoring tool for Serlui river in Kolasib district, Mizoram, India. International Journal of Academic Research \& Development, 3(2), pp.676-680.

42. Taloor, A.K., Pir, R.A., Adimalla, N., Ali, S., Manhas, D.S., Roy, S. and Singh, A.K. (2020). Spring water quality and discharge assessment in the Basantar watershed of Jammu Himalaya using geographic information system (GIS) and water quality index (WQI). Groundwater for sustainable Development, 10, 100364.

43. Thasangzuala, Z.R., Devi, G. P. and Mishra, B.P. (2014). Chemical characteristics of public drinking water in Aizawl city, Mizoram, India. International Journal of Green \& Herbal Chemistry, 4(1), pp. 9-16.

44. Tripathy, J. K. and Sahu, K. C. (2005). Seasonal hydrochemistry of groundwater in the Barrier Spit system of the Chilika Lagoon, India. Journal of Environmental Hydrology, 13.

45. Tuinstra, J. and van Wensem, J. (2014). Ecosystem services in sustainable groundwater management. Science of the total environment, 485, pp. 798-803.

46. Vishnu Radhan, R., Zainudin, Z., Sreekanth, G. B., Dhiman, R., Salleh, M. N. and Vethamony, P. (2017). Temporal water quality response in an urban river: a case study in peninsular Malaysia. Applied Water Science, 7(2), pp. 923-933.

47. Yadav, K. K., Gupta, N., Kumar, V., Sharma, S. and Arya, S. (2015). Water quality assessment of Pahuj River using water quality index at Unnao Balaji, MP, India. Int J Sci Basic Appl Res, 19(1), pp. 241-250. 